\title{
Use of Electronic Noses for Diagnosis of Digestive and Respiratory Diseases through the Breath
}

\author{
Carlos Sánchez ${ }^{1,2}$, J. Pedro Santos ${ }^{1}(\mathbb{C})$ and Jesús Lozano ${ }^{3, *(1)}$ \\ 1 Institute of Physics Technology and Information (CSIC), 28006 Madrid, Spain; carlos@updevices.com (C.S.); \\ jp.santos@csic.es (J.P.S.) \\ 2 Up Devices and Technologies, 28021 Madrid, Spain \\ 3 Industrial Engineering School, University of Extremadura, 06006 Badajoz, Spain \\ * Correspondence: jesuslozano@unex.es; Tel.: +34-924-289-300
}

Received: 12 January 2019; Accepted: 21 February 2019; Published: 28 February 2019

\begin{abstract}
The increased occurrence of chronic diseases related to lifestyle or environmental conditions may have a detrimental effect on long-term health if not diagnosed and controlled in time. For this reason, it is important to develop new noninvasive early diagnosis equipment that allows improvement of the current diagnostic methods. This, in turn, has led to an exponential development of technology applied to the medical sector, such as the electronic nose. In addition, the appearance of this type of technology has allowed the possibility of studying diseases from another point of view, such as through breath analysis. This paper presents a bibliographic review of past and recent studies, selecting those investigations in which a patient population was studied with electronic nose technology, in order to identify potential applications of this technology in the detection of respiratory and digestive diseases through the analysis of volatile organic compounds present in the breath.
\end{abstract}

Keywords: electronic nose; gas sensors; biomarkers; diseases; digestive system; respiratory system; volatile organic compounds; breath

\section{Introduction}

The relationship between aromas present in the breath and disease has been known by doctors for a several hundred years. The use of aromas to identify diseases dates back to the fourth century, when the doctor, based on experience, could determine what disease a patient was suffering. For example, a fruity aroma in the breath was identified as a sign of ketoacidosis associated with diabetes, and the smell of ammonia can be indicative of kidney failure. This method was not accurate, as it was necessary for the disease to be in an advanced stage to be detected by human olfaction. Based on this, electronic systems have been developed to diagnose diseases through the breath and to provide information about the state of the human body [1]. Human breath has a considerable amount of volatile organic compounds (VOCs) that are a product of metabolic activity. These VOCs can differ according to genetic or environmental factors such as age, weight, sex, lifestyle, or eating habits, and can influence the chemical composition of a person's breath, depending on the amount and concentrations of these compounds. Diseases can also cause an alteration of VOCs in the breath [2].

Currently, there has been an exponential development of technology in medical applications, in both the prevention and diagnosis or treatment of disorders. The growth in areas such as chemical sensors, microelectronic designs, material sciences, and artificial intelligence is contributing to the development of medical technology, and to improved health and increased life expectancy of the population. According to the World Health Organization (WHO), the average life expectancy in the world increased by five years in the period 2000-2016 [3]. The problem is that quality of life has not improved as much as life expectancy. The average increase in life years does not mean that this 
corresponds to a good state of health. People can suffer diseases and problems that cause a loss of quality of life without endangering their lives. On the other hand, health inequalities persist among different countries and people at different income levels [4].

One of the biggest challenges of modern medicine is to develop equipment that allows early diagnosis in a noninvasive way. This could avoid disease exacerbation, permitting control of the evolution of chronic patients in the medium and long term and maintaining their quality of life. It also would contribute to a reduction in hospital costs, as it could reduce the number of hospital/health center visits and the amount of medicine used. The principal limitation of the early detection of disease is that it is impossible to analyze healthy persons continuously, because this would be economically infeasible. In addition, the health system does not have the resources or the medical staff for this purpose. For this reason, the devices should be cheap and portable, so they can be available to more hospitals and health centers. On the other hand, this would open the possibility for patients to have devices at home to perform regular analysis.

These arguments and necessities have motivated the development of new technologies such as the electronic nose. The first electronic nose was developed in 1964 by Wilkens et al. [5], but it was not until 1982 when the electronic nose as a system using chemical sensors to classify odors was described by Persaud et al. [6]. In the 1980s, there was an evolution of this technology, which led to the creation of a technological sector that tried to imitate the olfactory systems of mammals [7]. Since then, the development of electronic noses has gone hand-in-hand with the technology being used in various sectors and different applications [8]. One is the medical sector, particularly the diagnosis and control of respiratory and digestive diseases. This technology could offer the possibility of diagnosing or evaluating disease states in a noninvasive and quick way with low-cost instruments.

\section{The Olfactory Organ and Electronic Nose}

Living organisms receive information about the surrounding environment through different sensory organs. Nowadays, the scientific community is focusing on the development and generation of systems and devices that can mimic the sensory organs: first, to replace the function of one of these organs in case of malfunction due to atrophy, pathology, or accident; and second, to be used in a wide variety of industrial applications in fields such as medicine, agriculture, food, environment, etc. Given that a deficiency in the ability to smell does not limit a person's normal life, except for the detection of gas leaks or fires, this technology becomes increasingly important in other applications $[9,10]$.

The electronic nose is capable of detecting, discriminating, and identifying different types of chemicals present in the headspace of a sample as VOCs. The device's response to smell is produced by the interaction between volatile compounds and sensors, whereas this function is done in the biological nose by the olfactory epithelium, which works as a transductor, as it generates electrical signals from chemical stimuli. These signals are preprocessed in the olfactory bulb, then transmitted to the brain, where they are stored. Finally, the data are used to identify odors in the learning stage. Analogously, in an electronic nose, an analogical-digital conversion is produced to preprocess the signals, with a microcontroller employed for this purpose. In this case, the data are stored in the database of a pattern recognition machine to identify the aromas that are learned. Figure 1 shows a comparison between the electronic nose and biological nose [10,11].

Due to the wide variety of applications that have been generated recently in several sectors, sensors based on different detection principles have been developed to satisfy the needs that have arisen. Sensors undergo a physical or chemical change by interacting at the molecular level when exposed to a gas. This process is reversible and allows the sensors to be used again in other tests [8]. A wide variety of sensors have been developed: metal oxide semiconductor (MOS), conducting polymer (CP), chemocapacitor (CAP), electrochemical (EC), metal oxide semiconductor field effect (MOSFET), surface acoustic wave (SAW), quartz crystal microbalance (QCM), bulk acoustic wave (BAW), fluorescence (FL), optical fiber live cell (OF-LC), catalytic field effect (CFET), calorimetric or catalytic bead (CB), 
carbon black composite (CBC), micro-electromechanical system (MEMS), photoionization detector (PID), and amperometry gas sensor (AGS) [12].

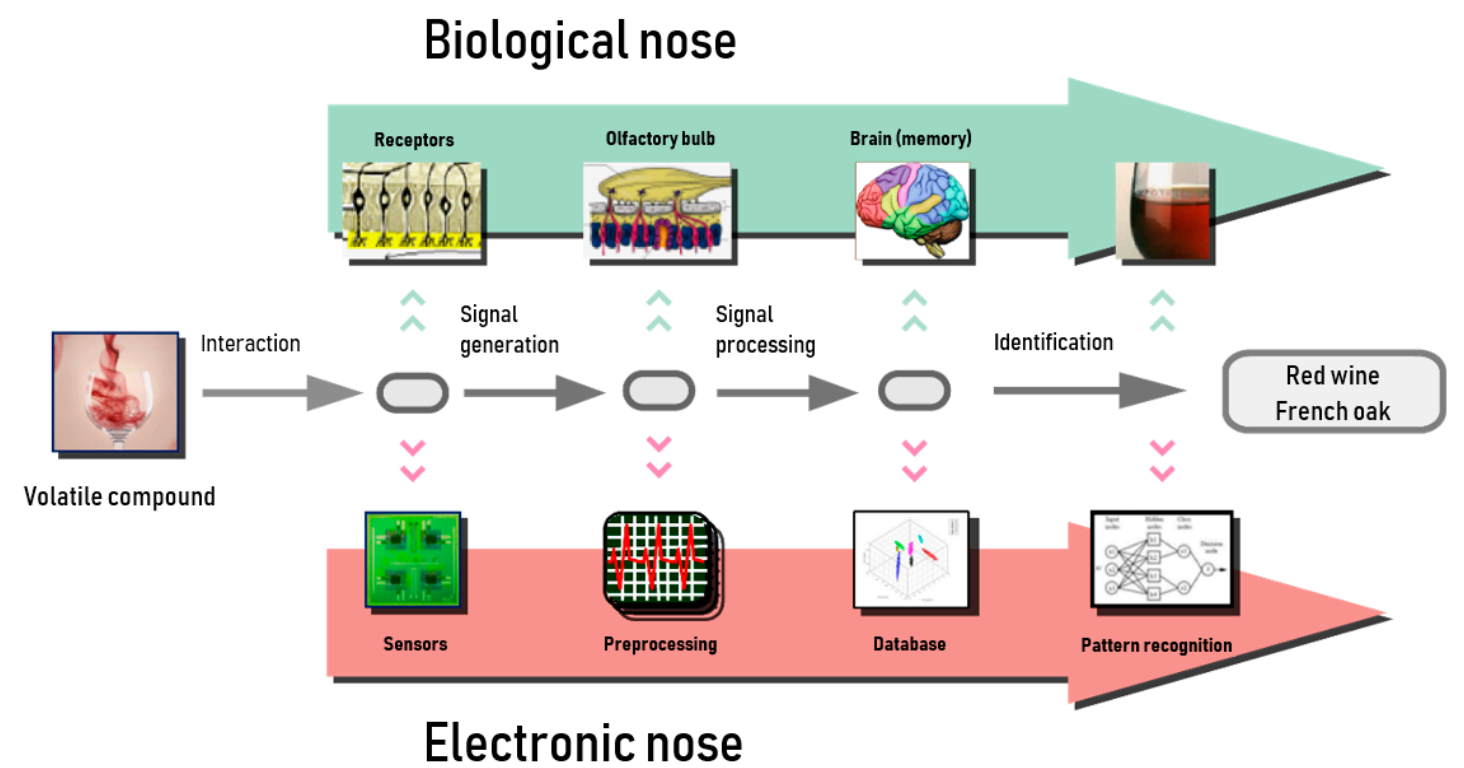

Figure 1. Schematics of electronic nose and biological olfactory system [13].

This offers a wide range of possibilities, so it is possible to use one type of sensor or another according to the application [8,12]. For example, sensors with good sensitivity are MOS, MOSFET, and AGS. SAW, FL, and OF-LC combine sensibility with specificity. However, the principal disadvantages of the gas sensor are slow recovery (MOS), drift in the response (MOS, CP, SAW), low noise immunity (PID), and lack of reproducibility between sensors of different sets (CP, MOSFET, QCM, SAW) and in the response of the same sensor in the long term. Because of this, it is normal to use a matrix of sensors of different types to avoid the disadvantages presented by each one separately and maximize their advantages [12,14].

\section{Biomarkers and Diseases}

In 1899, Thomson, who was interested in measuring the mass/charge ratio of an electron, created the first instrument similar to a mass spectrometer (MC), improving on the work previously done by Wien. In 1941, Martin and Synge published a paper describing the liquid-liquid chromatographic partition. However, it was not until 1952 when chromatography took on its gas-solid version (James and Martin). In later years, equipment was developed that used both techniques, which eliminated the disadvantages that each one presented separately $[15,16]$. One of the main problems encountered in the analysis of VOCs was the impossibility of capturing these compounds, as they are very volatile. This inconvenience was solved with the emergence of solid-phase microextraction (SPME) [17]. Since then, new techniques have been developed, such as gas chromatography-mass spectrometry (GC-MS), proton transfer reaction-mass spectrometry (PTR-MS), selected ion flow tube-mass spectrometry (SIFT-MS), field asymmetric ion mobility spectrometry (FAIMS), time-of-flight mass spectrometry (TOF-MS), ion mobility spectrometry (IMS), liquid chromatography-mass spectrometry (LC-MS), and high-performance liquid chromatography (HPLC).

With these techniques, it is possible to extract information about the respiratory or digestive system through the breath. However, the existence of VOCs in respiration does not necessarily imply that these volatile molecules are produced by the human body; rather, they can be produced in an exogenous process. For example, acetonitrile is commonly found in the breath of smokers, occurring exogenously. Exposure to a dangerous atmosphere, contaminants, or even certain medications can generate new compounds and also alter the concentration of other endogenous compounds [18]. 
Table 1 shows descriptions of different processes associated with oxidative stress and airway inflammation and the influence of these processes on the composition of VOCs in the breath. Endogenous compounds are produced by respiratory or digestive system cells, which metabolize the molecules present in the inspired air and generate others. When the cells function abnormally, they can alter the composition of VOCs in the breath. For example, oxidative stress is an imbalance of the normal state of the human body caused by the production of free radicals, which alters the composition of the compounds present in the breath as $\mathrm{H} 2 \mathrm{O} 2, \mathrm{CO}$, or 8-isoprostane $[19,20]$. Another example is the inflammation of airways, where the immune response produces an increase of various biomarkers in the breath $[19,21]$.

Table 1. Processes involved in different pathologies.

\begin{tabular}{|c|c|c|c|}
\hline Process & Description & Biomarker & References \\
\hline \multirow{4}{*}{$\begin{array}{c}\text { Marker of } \\
\text { oxidative stress }\end{array}$} & $\begin{array}{l}\text { Inflammation process in lung cells; eosinophils, } \\
\text { neutrophils, and macrophages produce reactive } \\
\text { oxygen species }\end{array}$ & $\mathrm{H}_{2} \mathrm{O}_{2}$ & {$[19,22,23]$} \\
\hline & $\begin{array}{l}\text { Increase of free radicals, which react to cell } \\
\text { membrane phospholipid, generating } \\
\text { 8-isoprostane }\end{array}$ & 8-isoprostane & {$[19,20]$} \\
\hline & $\begin{array}{l}\text { Oxidation of cell membrane phospholipids } \\
\text { produces a chain reaction, the targets of which } \\
\text { are polyunsaturated fatty acids, resulting in the } \\
\text { formation of unstable lipid hydroperoxides and } \\
\text { secondary carbonyl compounds, such as } \\
\text { aldehydic products }\end{array}$ & Malondialdehyde & [19] \\
\hline & $\begin{array}{l}\mathrm{CO} \text {, a marker of oxidative stress, is produced } \\
\text { by the stress protein hemoglobin oxygenase }\end{array}$ & $\mathrm{CO}$ & [21] \\
\hline \multirow{4}{*}{$\begin{array}{l}\text { Inflammation } \\
\text { of airways }\end{array}$} & $\begin{array}{l}\text { Immune response against infection produces } \\
\text { an inflammation process in cells, which } \\
\text { generate more NO than in a healthy person }\end{array}$ & Alveolar NO & [19] \\
\hline & $\begin{array}{l}\text { Cytokines * and chemokines are involved in } \\
\text { many aspects of the disease process in chronic } \\
\text { obstructive pulmonary disease (COPD), } \\
\text { including recruitment of neutrophils, } \\
\text { macrophages, T cells, and B cells }\end{array}$ & $\begin{array}{l}\text { Cytokines * and } \\
\text { chemokines }\end{array}$ & [19] \\
\hline & $\begin{array}{l}\text { Leukotrienes are muscle constrictors, such as in } \\
\text { lung muscle }\end{array}$ & $\begin{array}{l}\text { Leukotriene B4 and } \\
\text { prostaglandins }\end{array}$ & [19] \\
\hline & $\mathrm{CO}$ is a marker of inflammation & $\mathrm{CO}$ & [21] \\
\hline
\end{tabular}

Microorganisms that may be present in the digestive or respiratory tract, such as viruses, bacteria, or fungi, can also directly or indirectly alter the composition and concentration of VOCs in the breath. These cannot modify the concentration by themselves; otherwise, these microorganisms can affect the normal functioning of the cells of the body, causing the same effect. Therefore, the alteration of volatile compounds can have an exogenous or endogenous cause, which can be produced by a malfunction of the cells or by external biological agents [18].

\subsection{Endogenous Biomarkers}

The following section describes the pathologies detected by different chemical techniques of analysis that are mentioned in the bibliography consulted. Asthma and chronic obstructive pulmonary disease (COPD) are chronic diseases that cause difficulty breathing due to inflammation of the airways, which become rigid [24,25]. Inflammation of the epithelial cells causes increased concentrations of NO, pentane, isoprene, and ethane in the expired air in asthma (Lärstad et al. [26]) and ethane in 
the expired air in COPD (Paredi et al. [27]) (Table 2). This occurs with other diseases described in the bibliography, such as acute respiratory distress syndrome (ARDS), cystic fibrosis (CF), and lung cancer. ARDS is a pathology that prevents enough oxygen from reaching the lungs and the bloodstream [28]. CF is a genetic and chronic disorder that affects organs such as the pancreas, liver, kidneys, and intestine, causes difficulty breathing, and generates dense mucus in the airways [29]. A study by Antuni et al. [30] used NO and CO as biomarkers for the discrimination of this disease. In the case of $\mathrm{NO}$, the concentration of this biomarker decreases in patients with $\mathrm{CF}$ in comparison to healthy individuals. In the case of $\mathrm{CO}$, the concentration increases.

Finally, in lung cancer, the process of cell division is disrupted by the creation of new cells in an uncontrolled way and when they are not necessary, as well as allowing old or damaged cells to survive [31]. Bajtarevic et al. [32] employed isoprene, acetone, methanol, and benzene as biomarkers of lung cancer. The concentrations of these compounds decreased in patients with this disease in comparison with healthy persons. Table 2 shows chemical analysis techniques and biomarkers used to detect different diseases.

Table 2. Concentrations of biomarkers used in the detection of different diseases. NS, not stated; ppb, parts per billion; ppmv, parts per million by volume.

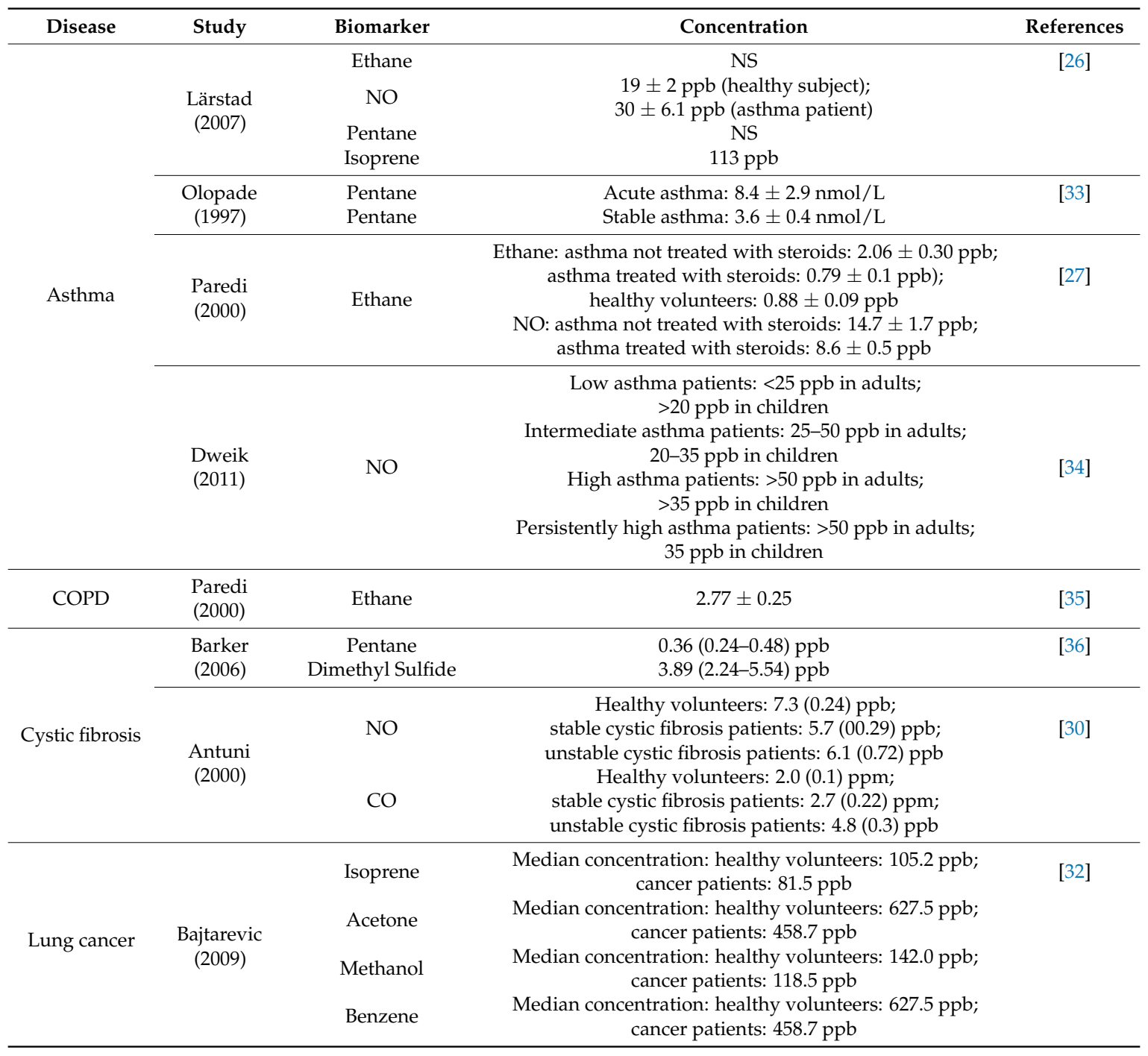


Table 2. Cont.

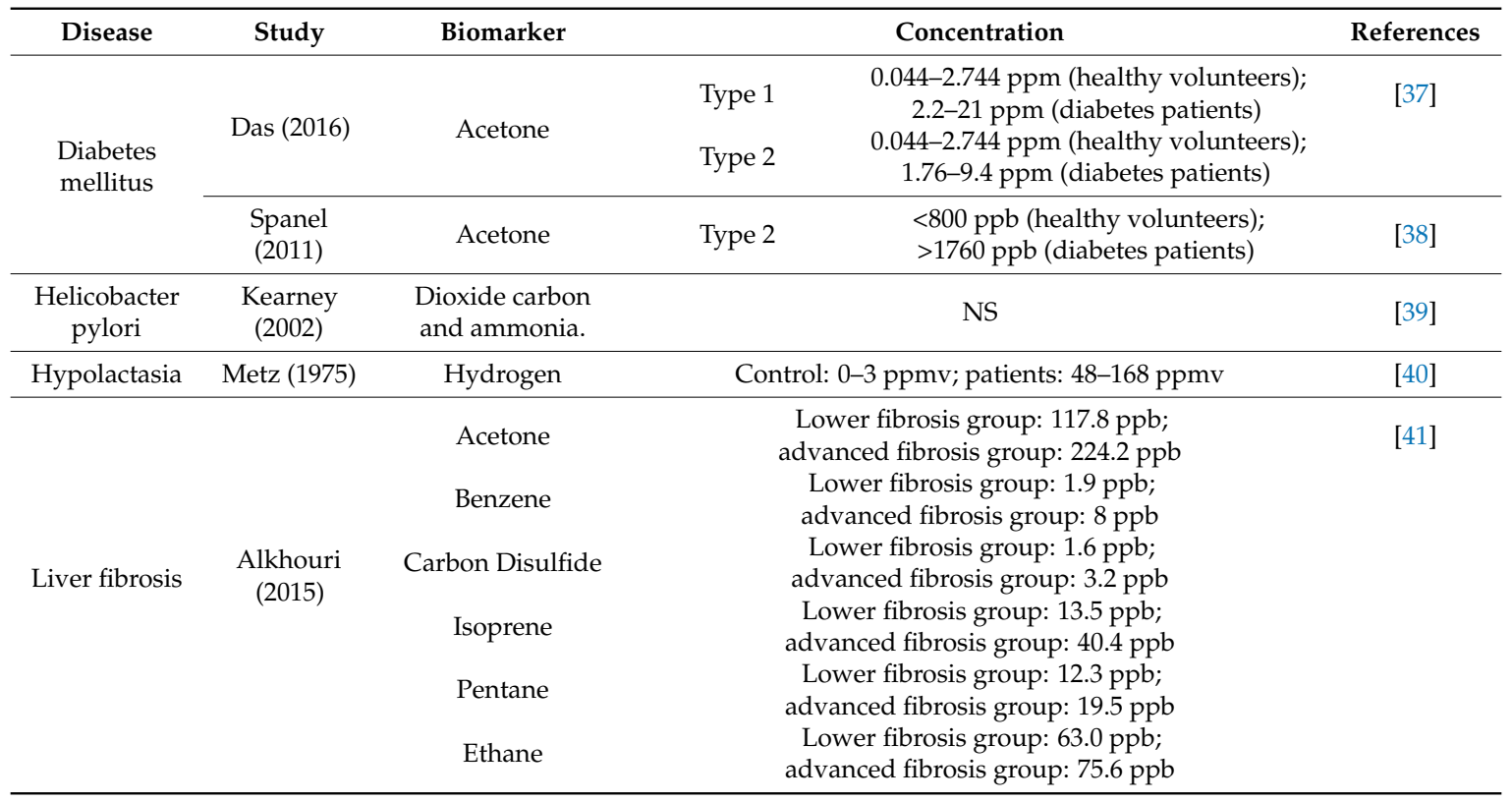

As already mentioned, diseases of the digestive system, such as diabetes mellitus, liver fibrosis, and hypolactasia, can alter the concentration of VOCs in the same way as respiratory diseases. Diabetes is a disease in which the body does not produce insulin or does not use it correctly [42]. Liver fibrosis is a disorder that causes decreased blood supply through the liver and produces the accumulation of scar tissue [43]. Das et al. [37] and Kearney et al. [39] used acetone as the major biomarker to detect both pathologies. The concentration of this compound increased in patients with these disorders in comparison with healthy persons. Lastly, hypolactasia is a deficiency of lactase (the enzyme that metabolizes lactose) in the intestinal mucosa, which causes this molecule to not be metabolized [44]. For the detection of this disorder, Alkhouri et al. [41] used hydrogen as a biomarker.

\subsection{Exogenous Biomarkers}

In this section, diseases generated by external pathogens, such as pneumonia and pulmonary tuberculosis, which produce exogenous volatile organic compounds, are described. Pneumonia is a lung infection that can be caused by many pathogenic agents, such as bacteria, viruses, or fungi [45], while tuberculosis is a bacterial infection (Mycobacterium tuberculosis) that mainly attacks the lungs or other parts of the organism [46]. However, it should be noted that there are diseases (e.g., cystic fibrosis and COPD) that predispose the patient to infections such as pneumonia [29]. Therefore, in this pathology it is common to find endogenous and exogenous VOCs in the breath. In order to determine whether a person is ill, it is necessary to know the aromatic profile of a healthy person. The concentrations of existing major compounds in the breath of healthy persons can be seen in Table 3 . 
Table 3. Major volatile organic compounds present in the breath of healthy individuals [47].

\begin{tabular}{cc}
\hline Compound & Concentration \\
\hline Water vapor & $5-6.3 \%$ \\
Nitrogen & $78.04 \%$ \\
Oxygen & $16 \%$ \\
Carbon dioxide & $4-5 \%$ \\
Hydrogen & $5 \%$ \\
Argon & $\mathrm{NS}$ \\
CO & $0-6 \mathrm{ppm}$ \\
Ammonia & $0.5-2 \mathrm{ppm}$ \\
Acetone, methanol, ethanol & $0.9 \% ;<1 \mathrm{ppm}$ \\
Hydrogen sulfide & $0-1.3 \mathrm{ppm}$ \\
NO & $10-50 \mathrm{ppb}$ \\
Carbonyl sulfide & $0-10 \mathrm{ppb}$ \\
Ethane & $0-10 \mathrm{ppb}$ \\
Pentane & $0-10 \mathrm{ppb}$ \\
Methane & $2-10 \mathrm{ppm}$ \\
\hline
\end{tabular}

\section{Traditional Methods of Diagnosis}

Traditionally, chemical analysis techniques have not been used to diagnose respiratory or digestive diseases, as these are very expensive. Breath analysis may mitigate some of the disadvantages of conventional diagnostic tests. Additionally, it could complement conventional methods as a screening tool. The main disadvantage of traditional diagnostic tests is that there is usually a long wait to conduct the test. In addition, some are invasive tests, which may require irradiation of the patient or a surgical procedure. In other cases, the test result is not obtained immediately, as in the case of cultures.

Both invasive and noninvasive diagnostic techniques are currently used. For example, spirometry and fractional exhaled nitric oxide (FeNO) are noninvasive techniques used to determine the patient's lung capacity, mainly used to diagnose diseases such as asthma and COPD. The sweat test and sputum cultures are also employed as noninvasive techniques for the diagnosis of cystic fibrosis (described by Gibson and Cooke [48] in 1959) and respiratory infections, respectively. On the other hand, diagnostic tests used to detect other diseases described in the bibliography are lung biopsy (lung cancer and lung sarcoidosis), chest x-ray (CXR) (ARDS and lung tuberculosis), endoscopy (lung cancer), and computed tomography (CT) (lung sarcoidosis and lung cancer).

\section{Recent Developments in Electronic Noses for the Diagnosis of Respiratory Diseases}

One of the major objectives in medicine today is to develop equipment and techniques to achieve early diagnosis of diseases. For this, it is necessary to develop devices that are portable, economical, and, above all, noninvasive, in order to reduce the risk to patients. In addition, this would contribute to decentralizing medical resources and facilitate access to these devices, reducing waiting lists. Until now, noninvasive tests that have been performed were based only on the chemical analysis of body fluids (feces, urine, and blood), but the possibility of analyzing the volatile compounds generated by the samples (as well as exhaled air) has not been explored.

Traditionally, chemical analysis techniques such as GC-MS and, to a lesser extent, the techniques described in Section 3 have been used to detect VOCs and the chemical composition of gaseous samples. With the evolution of gas sensors and the electronic nose in recent decades, they are beginning to be used as diagnostic methods. It is true that currently gas sensors are not as selective as chemical analysis equipment, but the electronic nose allows for much smaller and compact equipment, which offers a lot of possibilities.

This paper includes a summary of the specialized bibliography on the detection of respiratory and digestive diseases through the breath using an electronic nose (Table 4). It should be noted that the scientific research carried out in recent years is included here. Therefore, only the electronic noses used in such studies are described, with the intention that this paper may help to determine the current 
state of research in the field and be a starting point for future studies. In the bibliography, it is possible to find some authors who have used commercial electronic noses and others who have developed their own equipment adapted to specific applications. It should be noted that the diagnostic tests employed are used to corroborate the results of the studies, but they do not have to be standard tests. Most of the authors described in this paper used a commercial electronic nose, the Cyranose 320, which has a matrix of 32 sensors of carbon black polymer. Only a few used a self-developed electronic nose optimized for a specific application.

Asthma is one of the respiratory diseases that affects the largest number of people in the world, based on more papers being found on this disease. The population studied by Dragonieri et al. [49,50] was 40 adult subjects, and they employed the Cyranose 320. In data processing, they used principal component analysis (PCA) as an alternative diagnostic test to corroborate the results obtained by using spirometry and FeNO. The other authors studying asthma used similar population sizes, and also used the Cyranose 320. They used spirometry or FeNO as a diagnostic test. While not all authors used the same techniques in the processing phase, they employed PCA and other techniques such as receiver operating characteristic (ROC) curve and neural network algorithms (ANNs). On the other hand, Brinkman et al. [51] studied a smaller population of subjects and performed the measurements using three electronic noses, two commercial (Cyranose 320, carbon black polymer sensors) and Tor Vergata Electronic Nose (QCM sensors; developed by the Sensors Group at the University of Rome Tor Vergata, along with the Departments of Electronic Engineering and Chemical Science and Technology), and one home-developed incorporating metal oxide semiconductor sensors.

In the case of COPD, a variety of scientific articles were found that used the same two commercial electronic noses as in the previous case: Cyranose 320 and Tor Vergata Electronic Nose. Dymerski et al. [52] used an electronic nose formed by commercial sensors from Figaro. In this case, the samples were generated in the laboratory, unlike in the other studies. To distinguish between patients and healthy individuals, Paredi et al. [35] employed three biomarkers: ethanol, CO, and $\mathrm{NO}$, the concentrations of which in the exhaled air of patients with COPD increased compared to the healthy people. The literature found for lung cancer varies in terms of the type of cancer described; each author focused on the detection of one, studying populations of between 50 and 100 adult patients, using the commercial electronic noses that were used by other authors.

In the detection of pulmonary tuberculosis, a wider variety of authors were found to use different electronic noses with different types of sensors: commercial ones such as Cyranose 320, Aeonose, and Bloodhound BH1114, and home-developed equipment, such as Zelota et al. [53] using QCM, Bruins et al. [54] using metal oxide semiconductor sensors, and Fend et al. [55] using conducting polymer sensors.

For the rest of the pathologies shown in the table, fewer bibliographical references were found. Saasa et al. [56] discriminated between samples of patients with diabetes mellitus by detecting acetone. On the other hand, Schnabel et al. [57] stand out, discriminating between patients with pneumonia and healthy people. They studied a remarkable sample of 125 adult patients using a commercial electronic nose called DiagNose, which uses metal oxide sensors. 
Table 4. Biomedical applications developed using commercial and experimental electronic noses.

\begin{tabular}{|c|c|c|c|c|c|c|c|c|}
\hline Application & Author & Population Characteristics & Sensor Technology & $\begin{array}{l}\text { Number } \\
\text { of Sensors }\end{array}$ & $\begin{array}{c}\text { Data } \\
\text { Processing } \\
\text { Algorithm }\end{array}$ & Diagnosis & $\begin{array}{c}\text { Other } \\
\text { Techniques }\end{array}$ & References \\
\hline \multirow{5}{*}{ Asthma } & $\begin{array}{l}\text { Dragonieri } \\
\quad(2007)\end{array}$ & $\begin{array}{l}\text { 40 adult subjects, nonsmokers, aged 18-75, } \\
\text { without any other acute or chronic disease } \\
\text { besides asthma (mixed group) } \\
\text { - Group 1: } 10 \text { patients, } 25.1 \pm 5.9 \text { years, } \\
\text { intermittent-mild asthma } \\
\text { - Group 2: } 10 \text { patients, } 26.8 \pm 6.4 \text { years } \\
\text { (control group) } \\
\text { - Group 3: } 10 \text { patients, } 49.5 \pm 12.0 \text { years, } \\
\text { moderate-severe persistent asthma } \\
\text { - Group 4: } 10 \text { patients, } 57.3 \pm 7.1 \text { years } \\
\text { (control group) }\end{array}$ & Polymer nanocomposite sensor & 32 & PCA & $\begin{array}{l}\text { Spirometry, } \\
\text { FeNO }\end{array}$ & GC-MS & [49] \\
\hline & $\begin{array}{l}\text { Montuschi } \\
\quad(2010)\end{array}$ & $\begin{array}{l}\text { 52 adult subjects, nonsmokers } \\
\text { (mixed group) } \\
\text { - Group 1: } 27 \text { asthma patients, } \\
\quad 39 \pm 3 \text { years } \\
\text { - Group 2: } 24 \text { patients, } 33 \pm 3 \text { years } \\
\quad \text { (control group) }\end{array}$ & $\begin{array}{l}\text { QCM gas sensors coated by molecular } \\
\text { metalloporphyrin film }\end{array}$ & 8 & PCA and FNN & $\mathrm{FeNO}$ & GC-MS & [58] \\
\hline & $\begin{array}{l}\text { Santonico } \\
\quad(2014)\end{array}$ & 58 subjects & $\begin{array}{l}\text { Carbon black polymer (Cyranose } \\
\text { C320)/QCM covered with } \\
\text { metalloporphyrin film (Tor Vergata } \\
\text { Electronic Nose)/metal oxide } \\
\text { semiconductor } \\
\end{array}$ & $32 / \mathrm{NS} / \mathrm{NS}$ & ROC & FeNO & $\begin{array}{c}\text { FAIMS } \\
\text { (Owlstone) }\end{array}$ & [59] \\
\hline & $\begin{array}{l}\text { Brinkman } \\
\quad(2017)\end{array}$ & $\begin{array}{l}28 \text { subjects } \\
\text { - } \quad 23 \text { asthma patients, } 25 \text { (21-31) years } \\
\text { - } \quad 5 \text { healthy volunteers, control group }\end{array}$ & $\begin{array}{l}\text { Carbon black polymer (Cyranose } \\
\text { C320)/QCM covered with } \\
\text { metalloporphyrin film (Tor Vergata } \\
\text { Electronic Nose)/metal oxide } \\
\text { semiconductor }\end{array}$ & $32 / \mathrm{NS} / \mathrm{NS}$ & PCA & $\begin{array}{l}\text { FeNO and } \\
\text { spirometry }\end{array}$ & $\begin{array}{c}\text { FAIMS } \\
\text { (Owlstone) } \\
\text { and GC-MS }\end{array}$ & [51] \\
\hline & $\begin{array}{l}\text { Cavaleiro } \\
\text { (2018) }\end{array}$ & 60 subjects, aged $6-18$ years (mixed group) & $\begin{array}{l}\text { Polymer nanocomposite sensor } \\
\text { (Cyranose 320) }\end{array}$ & 32 & Clustering & $\begin{array}{l}\text { FeNO and } \\
\text { spirometry }\end{array}$ & GC-MS & [60] \\
\hline
\end{tabular}


Table 4. Cont.

\begin{tabular}{|c|c|c|c|c|c|c|c|c|}
\hline Application & Author & Population Characteristics & Sensor Technology & $\begin{array}{l}\text { Number } \\
\text { of Sensors }\end{array}$ & $\begin{array}{c}\text { Data } \\
\text { Processing } \\
\text { Algorithm } \\
\end{array}$ & Diagnosis & $\begin{array}{c}\text { Other } \\
\text { Techniques }\end{array}$ & References \\
\hline \multirow{5}{*}{$\begin{array}{l}\text { Chronic } \\
\text { obstructive } \\
\text { pulmonary } \\
\text { disease }\end{array}$} & $\begin{array}{l}\text { Paredi } \\
(2000)\end{array}$ & $\begin{array}{l}36 \text { subjects (mixed group) } \\
\text { - Group 1: } 12 \text { nonsteroid-treated } \\
\text { - } \quad \text { Group 2: } 10 \text { steroid-treated patients, } \\
\quad 58 \pm 2 \text { years } \\
\text { - Group 3: } 14 \text { healthy subjects, } \\
\quad 33 \pm 3 \text { years (control group) }\end{array}$ & NS & NS & NS & NS & NS & [35] \\
\hline & $\begin{array}{l}\text { Capuano } \\
\text { (2010) }\end{array}$ & $\begin{array}{l}20 \text { subjects (mixed group) } \\
\text { - Group 1: 12 COPD patients, } \\
\text { ex-smokers, therapy not based } \\
\text { on cortisone } \\
\text { - Group 2: } 8 \text { healthy volunteers } \\
\text { (control group) }\end{array}$ & $\begin{array}{l}\text { QMC gas sensor with } \\
\text { metalloporphyrin films }\end{array}$ & 7 & PLS-DA & NS & NS & [61] \\
\hline & $\begin{array}{l}\text { Hattesohl } \\
\text { (2011) }\end{array}$ & $\begin{array}{l}33 \text { subjects (mixed group) } \\
\text { - } \quad \text { Group 1: } 10 \text { COPD patients } \\
-\quad \text { Group 2: } 23 \text { patients (control group) }\end{array}$ & $\begin{array}{l}\text { Polymer nanocomposite sensor } \\
\text { (Cyranose 320) }\end{array}$ & 32 & $\begin{array}{l}\text { LDA, MD, } \\
\text { CVVs, canonical } \\
\text { plot }\end{array}$ & Spirometry & GC-MS & [62] \\
\hline & $\begin{array}{l}\text { Dymerski } \\
\text { (2013) }\end{array}$ & In vitro experiments & $\begin{array}{c}\text { SAW / BAW sensors (TGS 880, TGS } 825, \\
\text { TGS 826, TGS 822, TGS 2610, TGS } 2602 \\
\text { by Figaro) }\end{array}$ & 6 & PCA & NS & NS & [52] \\
\hline & Bofan (2013) & $\begin{array}{l}24 \text { adult subjects, ex-smokers, } \\
68 \pm 1.7 \text { years, with smoking history of } 39.5 \\
(24.2-63.3) \text { years without other acute or } \\
\text { chronic disease besides COPD or nonatopic } \\
\text { COPD and without inhaled or oral } \\
\text { corticosteroids (mixed group) }\end{array}$ & $\begin{array}{l}\text { Polymer nanocomposite and inorganic } \\
\text { conductor sensor (carbon black) } \\
\text { (Cyranose 320) }\end{array}$ & 32 & $\begin{array}{l}\text { Pattern } \\
\text { recognition } \\
\text { algorithm }\end{array}$ & $\begin{array}{l}\text { Spirometry } \\
\text { and FeNO }\end{array}$ & $\begin{array}{l}\text { GC-MS, NMR } \\
\text { spectroscopy, } \\
\text { and LC-MS }\end{array}$ & [63] \\
\hline $\begin{array}{l}\text { Acute } \\
\text { respiratory } \\
\text { distress } \\
\text { syndrome }\end{array}$ & Bos (2014) & $\begin{array}{l}\text { 180 subjects (mixed group) } \\
\text { - } \quad \text { Group 1: } 58 \text { ARDS patients, } \\
\text { - } \quad \text { (54-78) years } \\
\text { - } 56 \text { (49-62) years } \\
\text { - } \quad \text { Group 3: } 19 \text { cardiogenic pulmonary } \\
\text { edema patients, } 71 \text { (63-79) years } \\
\text { - Group 4: } 92 \text { healthy volunteers, } \\
\text { 64 (50-75) years (control group) }\end{array}$ & Polymer nanocomposite sensor & 32 & ROC & CXR & GC-MS & [64] \\
\hline
\end{tabular}


Table 4. Cont.

\begin{tabular}{|c|c|c|c|c|c|c|c|c|}
\hline Application & Author & Population Characteristics & Sensor Technology & $\begin{array}{l}\text { Number } \\
\text { of Sensors }\end{array}$ & $\begin{array}{c}\text { Data } \\
\text { Processing } \\
\text { Algorithm }\end{array}$ & Diagnosis & $\begin{array}{c}\text { Other } \\
\text { Techniques }\end{array}$ & Reference \\
\hline $\begin{array}{l}\text { Pulmonary } \\
\text { sarcoidosis }\end{array}$ & $\begin{array}{l}\text { Dragonieri } \\
\quad(2013)\end{array}$ & $\begin{array}{l}\text { 31 subjects (mixed group) } \\
\text { - Group 1: } 11 \text { patients, } 48.4 \pm 9.0 \text { years, } \\
\text { untreated pulmonary sarcoidosis } \\
\text { - Group 2: } 20 \text { patients, } 49.7 \pm 7.9 \text { years, } \\
\text { treated pulmonary sarcoidosis } \\
\text { - Group 3: } 25 \text { patients, } 39.6 \pm 14.1 \text { years } \\
\text { (control group) }\end{array}$ & $\begin{array}{l}\text { Polymer nanocomposite sensor } \\
\text { (Cyranose 320) }\end{array}$ & 32 & $\begin{array}{l}\text { PCA, CDA ROC } \\
\text { curves }\end{array}$ & $\begin{array}{l}\text { CXR, CT, } \\
\text { biopsy }\end{array}$ & $\begin{array}{l}\text { GC-MS, } \\
\text { TOF-MS, IMS }\end{array}$ & [65] \\
\hline $\begin{array}{l}\text { Cystic } \\
\text { fibrosis }\end{array}$ & Paff (2013) & $\begin{array}{l}48 \text { subjects (mixed group) } \\
\text { - } \quad \text { Group 1: } 25 \text { patients, } 11.4 \text { years } \\
\text { - } \quad \text { Positive bacterial cultures: } \\
\text { - } \quad \text { Pulmonary exacerbation: } 9 / 25 \text { patients } \\
\text { - } \quad \text { Group 2: } 23 \text { patients, } 9.3 \text { years } \\
\quad \text { (control group) }\end{array}$ & $\begin{array}{l}\text { Polymer nanocomposite sensor } \\
\text { (Cyranose 320) }\end{array}$ & 32 & $\begin{array}{l}\text { PCA, ROC } \\
\text { curves, and } \\
\text { CDA }\end{array}$ & $\begin{array}{l}\text { Spirometry } \\
\text { and sputum } \\
\text { culture }\end{array}$ & GC-MS & [66] \\
\hline $\begin{array}{c}\text { Primary } \\
\text { ciliary } \\
\text { dyskinesia }\end{array}$ & Paff (2013) & $\begin{array}{l}48 \text { subjects (mixed group) } \\
\text { - } \quad \text { Group 1: } 25 \text { patients, } 10.7 \text { years } \\
\text { - } \quad \text { Positive bacterial cultures: } \\
\text { - } \quad \text { Pulmonary exacerbation: } 8 / 25 \text { patients } \\
\text { - } \quad \text { Group 2: } 23 \text { patients, } 9.3 \text { years } \\
\quad \text { (control group) }\end{array}$ & $\begin{array}{l}\text { Polymer nanocomposite sensor } \\
\text { (Cyranose 320) }\end{array}$ & 32 & $\begin{array}{c}\text { PCA, ROC } \\
\text { curves, } \\
\text { and CDA }\end{array}$ & $\begin{array}{l}\text { Spirometry } \\
\text { and sputum } \\
\text { culture }\end{array}$ & GC-MS & [66] \\
\hline
\end{tabular}


Table 4. Cont.

\begin{tabular}{|c|c|c|c|c|c|c|c|c|}
\hline Application & Author & Population Characteristics & Sensor Technology & $\begin{array}{l}\text { Number } \\
\text { of Sensors }\end{array}$ & $\begin{array}{c}\text { Data } \\
\text { Processing } \\
\text { Algorithm }\end{array}$ & Diagnosis & $\begin{array}{c}\text { Other } \\
\text { Techniques }\end{array}$ & References \\
\hline \multirow{4}{*}{ Lung cancer } & $\begin{array}{l}\text { Di Natale } \\
\text { (2003) }\end{array}$ & $\begin{array}{l}\text { 50 subjects (mixed group) } \\
\text { - Group 1: } 42 \text { patients with various } \\
\text { forms of cancer not showing any } \\
\text { other disease } \\
\text { - Group 2: } 8 \text { patients without respiratory } \\
\text { disease not taking any medication }\end{array}$ & $\begin{array}{l}\text { QCM gas sensors coated with } \\
\text { metalloporphyrin molecular film }\end{array}$ & 8 & PLS-DA & NS & GC-MS & [67] \\
\hline & $\begin{array}{l}\text { Machado } \\
\text { (2005) }\end{array}$ & $\begin{array}{l}59 \text { subjects (mixed group) } \\
\text { - } \quad \text { Group 1: } 14 \text { patients, } 64 \pm 3 \text { years, } \\
\text { with untreated } \\
\text { bronchogenic carcinoma } \\
\text { - } 13 \text { patients with non-small-cell cancer } \\
\text { - } \quad 1 \text { patient with small-cell cancer } \\
\text { Group 2: } 45 \text { patients, } 38 \pm 2 \text { years } \\
\quad \text { (control group) }\end{array}$ & $\begin{array}{l}\text { Polymer nanocomposite sensor } \\
\text { (Cyranose 320) }\end{array}$ & 32 & $\begin{array}{l}\text { PCA, SVM, and } \\
\text { CDA }\end{array}$ & $\begin{array}{l}\text { CXR and } \\
\text { biopsy }\end{array}$ & GC-MS & [68] \\
\hline & $\begin{array}{l}\text { Dragonieri } \\
\quad(2009)\end{array}$ & $\begin{array}{l}\text { 30 subjects (mixed group) } \\
\text { - Group 1: } 10 \text { NSCLC patients, } \\
66.4 \pm 9.0 \text { years: } 2 \text { current smokers, } \\
7 \text { ex-smokers, } 1 \text { never smoked } \\
\text { - Group 2: } 10 \text { COPD patients, } \\
\text { 61.4 } \pm 5.5 \text { years: } 6 \text { current smokers, } \\
4 \text { ex-smokers } \\
\text { - Group 3: } 10 \text { healthy volunteers, } \\
\text { 58.3 } \pm 8.1 \text { years, never smoked } \\
\text { (control group) }\end{array}$ & $\begin{array}{l}\text { Polymer nanocomposite sensor } \\
\quad \text { (Cyranose 320) }\end{array}$ & 32 & CDA, CVV, PCA & $\mathrm{CT}$ & GC-MS & [69] \\
\hline & $\begin{array}{l}\text { Dragonieri } \\
\quad(2012)\end{array}$ & $\begin{array}{l}39 \text { subjects (mixed group) } \\
\text { - Group 1: } 13 \text { patients, } 60.9 \pm 12.2 \text { years, } \\
\text { with confirmed diagnosis of MPM } \\
\text { Group 2: } 13 \text { subjects, } 67.2 \pm 9.8 \text { years, } \\
\text { long-term professional exposure } \\
\text { to asbestos } \\
\text { - Group 3: } 13 \text { subjects, } 52.2 \pm 16 \text { years, } \\
\text { no asbestos exposure (control group) }\end{array}$ & $\begin{array}{l}\text { Polymer nanocomposite sensor } \\
\text { (Cyranose 320) }\end{array}$ & 32 & $\begin{array}{l}\text { CVA, PCA, and } \\
\text { ROC }\end{array}$ & NS & GC-MS & [70] \\
\hline
\end{tabular}


Table 4. Cont.

\begin{tabular}{|c|c|c|c|c|c|c|c|c|}
\hline Application & Author & Population Characteristics & Sensor Technology & $\begin{array}{l}\text { Number } \\
\text { of Sensors }\end{array}$ & $\begin{array}{c}\text { Data } \\
\text { Processing } \\
\text { Algorithm }\end{array}$ & Diagnosis & $\begin{array}{c}\text { Other } \\
\text { Techniques }\end{array}$ & References \\
\hline Lung cancer & $\begin{array}{l}\text { D'Amico } \\
\text { (2010) }\end{array}$ & $\begin{array}{l}\text { 98 adult subjects, 50-70 years (mixed group) } \\
\text { - Group 1: } 56 \text { patients with primary } \\
\text { lung cancer, ex-smokers, not under } \\
\text { oncological therapy, at least } 6 \text { months } \\
\text { from last intervention } \\
\text { - Group 2: } 36 \text { patients with normal lung } \\
\text { function, negative history of chest } \\
\text { symptoms, nonsmokers, no history of } \\
\text { respiratory disease (control group) }\end{array}$ & QCM gas sensors & 8 & PLS-DA & Endoscopy & GC-MS & {$[23,71]$} \\
\hline \multirow{3}{*}{ Pneumonia } & $\begin{array}{l}\text { Hockstein } \\
\quad(2005)\end{array}$ & $\begin{array}{l}25 \text { subjects (mixed group) } \\
\text { - } \quad \text { Group 1: } 13 \text { patients with } \\
\text { diagnosed pneumonia } \\
\text { - } \quad \text { Group 2: } 12 \text { patients } \\
\text { without pneumonia }\end{array}$ & $\begin{array}{l}\text { Polymer nanocomposite sensor } \\
\text { (Cyranose 320) }\end{array}$ & 32 & SMV and PCA & CT & GC-MS & [72] \\
\hline & Chiu (2015) & In vitro experiment & $\begin{array}{l}\text { Polymer-carbon composite with } \\
\text { polymers on chemical sensor array }\end{array}$ & 8 & CRBM & $\begin{array}{c}\text { CXR, blood } \\
\text { draw, and } \\
\text { sputum } \\
\text { culture }\end{array}$ & GC-MS & [73] \\
\hline & $\begin{array}{l}\text { Schnabel } \\
\text { (2015) }\end{array}$ & $\begin{array}{l}\text { 125 subjects (mixed group) } \\
\text { - Group 1: } 33 \text { pneumonia patients, } \\
\text { 62 (20-82) years, subject to BAL } \\
\text { - } \quad \text { Group 2: } 39 \text { pneumonia patients, } \\
\text { 57 (23-82) years } \\
\text { - Group 3: } 53 \text { patients, } 60 \text { (34-85) } \\
\quad \text { (control group) }\end{array}$ & MOS sensors (DiagNose) & NS & $\begin{array}{l}\text { PCA and ROC } \\
\text { curves }\end{array}$ & $\mathrm{CT}$ & GC-MS & [57] \\
\hline $\begin{array}{l}\text { Pulmonary } \\
\text { tuberculosis }\end{array}$ & Pavlou (2004) & In vitro experiment & Gas-sensor array (Bloodhound BH114) & 14 & $\begin{array}{c}\text { PCA, } \\
\text { optimization of } \\
\text { BP-FNN, } \\
\text { multivariate } \\
\text { techniques, }\end{array}$ & CXR & NS & [74] \\
\hline
\end{tabular}


Table 4. Cont.

\begin{tabular}{|c|c|c|c|c|c|c|c|c|}
\hline Application & Author & Population Characteristics & Sensor Technology & $\begin{array}{l}\text { Number } \\
\text { of Sensors }\end{array}$ & $\begin{array}{c}\text { Data } \\
\text { Processing } \\
\text { Algorithm }\end{array}$ & Diagnosis & $\begin{array}{c}\text { Other } \\
\text { Techniques }\end{array}$ & References \\
\hline \multirow{5}{*}{$\begin{array}{l}\text { Pulmonary } \\
\text { tuberculosis }\end{array}$} & Fend (2006) & $\begin{array}{l}\text { 330 patients (mixed group) } \\
\text { - } \quad 188 \text { pulmonary tuberculosis patients: } \\
53.7 \% \text { HIV patients, } 31.4 \% \text { smokers } \\
\text { - } 142 \text { nonpulmonary tuberculosis } \\
\text { patients: } 29.6 \% \text { HIV patients, } \\
9.2 \% \text { smokers }\end{array}$ & $\mathrm{CP}$ sensor & 14 & $\begin{array}{l}\text { PCA, DFA, and } \\
\text { ANN }\end{array}$ & $\begin{array}{l}\text { CXR and } \\
\text { sputum } \\
\text { culture }\end{array}$ & GC-MS & [55] \\
\hline & Bruins (2013) & $\begin{array}{l}30 \text { patients (mixed group). } \\
\text { - } \quad \text { Group 1: } 15 \text { pulmonary tuberculosis } \\
\text { patients, 32 (21-58) years } \\
\text { - } \quad \text { Group 2: } 15 \text { healthy volunteers, } \\
\quad 30 \text { (18-58) years (control group) }\end{array}$ & $\begin{array}{c}\text { MOS sensor: } \\
\text { AS-MLC, AS-MLN, AS-MLK, AS-MLV }\end{array}$ & $\begin{array}{l}12 \text { (4 types } \\
\text { of sensors } \\
\text { in } \\
\text { triplicate) }\end{array}$ & ANN & $\begin{array}{l}\text { CXR and } \\
\text { microbiological } \\
\text { culture }\end{array}$ & GC-MS & [54] \\
\hline & Coronel (2017) & $\begin{array}{l}\text { 110 subjects (mixed group) } \\
\text { - Group 1: } 47 \text { pulmonary tuberculosis } \\
\text { patients, } 34.6 \text { years } \\
\text { - Group 2: } 14 \text { COPD or asthma patients, } \\
\text { - 54.5 years } \\
\text { - Group 3: } 49 \text { patients (control group) }\end{array}$ & MOS sensors (Aeonose) & NS & ROC curve & CXR & GC-MS & [75] \\
\hline & Zelota (2017) & $\begin{array}{l}71 \text { subjects (mixed group) } \\
\text { - Group 1: } 31 \text { pulmonary tuberculosis } \\
\text { and HIV patients, } 28.7 \pm 7.2 \text { years } \\
\text { - Group 2: } 20 \text { pulmonary tuberculosis } \\
\text { patients without HIV, } 39 \pm 9.3 \text { years } \\
\text { - Group: } 20 \text { healthy volunteers, } \\
\quad 33 \pm 11 \text { years (control group) }\end{array}$ & $\begin{array}{l}\text { QCM gas sensors coated by } \\
\text { metalloporphyrin molecular film }\end{array}$ & 8 & PCA & CXR & GC-MS & [53] \\
\hline & $\begin{array}{l}\text { Mohamed } \\
(2017)\end{array}$ & $\begin{array}{l}\text { 500 patients (mixed group) } \\
\text { - Group 1: } 260 \text { pulmonary tuberculosis } \\
\text { patients, } 41.72 \pm 16.03 \text { years } \\
\text { Group 2: } 204 \text { healthy volunteers, } \\
\quad 43.38 \pm 12.42 \text { years (control group) }\end{array}$ & MOS sensor & 10 & PCA and ANN & $\begin{array}{l}\text { Physical } \\
\text { examination } \\
\text { and routine } \\
\text { laboratory } \\
\text { analyses, } \\
\text { including CXR }\end{array}$ & GC-MS & [76] \\
\hline $\begin{array}{l}\text { Diabetes } \\
\text { mellitus }\end{array}$ & Saasa (2018) & NS & $\mathrm{QCL}, \mathrm{LAP}$, and chemoresistive sensors & NS & NS & NS & $\begin{array}{c}\text { GC-MS, } \\
\text { LC-MS, HPLC, } \\
\text { PTR-MS, and } \\
\text { SIFT-MS }\end{array}$ & [56] \\
\hline
\end{tabular}




\section{Future and Challenges}

Commercial electronic noses, used by most researchers, are designed for general use and are not optimized to detect the biomarkers of the diseases of interest. For medical applications, it is necessary to design specific sensors and optimized electronic noses, since it is an extremely complex sector, and it is a critical factor for the diagnosis and control of pathologies to be effective. In the medical sector, it is necessary to develop equipment that allows early diagnosis of diseases, enables simple and effective control, and is noninvasive.

On the one hand, this would allow health centers and small hospitals to have access to this type of equipment for the diagnosis and control of diseases (due to its lower cost) and thus minimize waiting lists. On the other hand, this would provide an opportunity for patients to have devices at home. In addition, in conjunction with the evolution of mobile technologies and Internet communication, it would allow patients to diagnose and control diseases from home by themselves or with remote medical supervision. It could even permit these types of sensors to be connected to phones either by incorporating them or through a gadget. The tendency of medicine is to advance along this line so that analyses and explorations can be performed at a distance. It is hospitals and health insurers themselves that could provide these types of devices to patients. In this way, it would be possible to achieve a unified protocol of measurement from the breath that is simple for patients to perform.

It is a promising technology for the diagnosis of respiratory and digestive diseases in a noninvasive way, since it allows the development of portable and cost-effective equipment. This is a key factor for this technology to succeed. However, current sensors still present complications that limit their operation. Therefore, one of the challenges from a technological point of view is to improve the selectivity of these sensors and their sensitivity to lower concentrations. To this end, it is important to use and develop new nanomaterials that can significantly improve selectivity and reduce the size and consumption, essential issues for miniaturization. It is therefore perhaps more important to focus efforts on developing technology that would enable these devices to be used in this application, and then study which is the ideal methodology to take samples in patients that is easy for a person without medical education to do.

\section{Conclusions}

Electronic nose technology has evolved remarkably in the last decade. Many researchers have focused their efforts on developing this type of equipment in a multitude of sectors, such as food, medicine, environment, and detection of hazardous materials.

This study presents a bibliographic review of research done on the use of the electronic nose for the detection of respiratory and digestive diseases through the breath. This technology bases its design and operation on the human sensory organ. The e-nose technology permits the study of diseases from a new approach, since until now analytical tests have focused exclusively on blood, urine, or feces samples, which allowed additional information to be obtained and studied. Although this technology is still in development and currently has some limitations, it has several advantages over other diagnostic methods. The ability to take measurements through the breath makes it possible to conduct analyses noninvasively, eliminating risks to the patient.

In addition, it would allow the production of portable equipment at a lower price than other equipment available in the market, giving health centers and hospitals greater access to this equipment. With the evolution in recent years and current development (improvement and miniaturization of gas sensors), the electronic nose is presented as a promising technology that should contribute to improving the quality of life of patients with chronic pathologies as well as early diagnosis of different diseases, contributing to the reduction of direct and indirect costs of the health system.

The purpose of this paper is to demonstrate the viability of this technology through a large number of studies done in this regard. From now on, it will be necessary to improve and solve the problems presented by the e-nose, fine-tuning this technology for the different applications in which it is intended to be used. This will require a great effort on the part of the research community, but once 
these problems have been solved, this technology should result in a great advance in the control and diagnosis of diseases, and satisfy many other needs that currently exist in the medical sector.

Funding: This research was funded by Department of Education and Research of the Madrid Autonomous Community (Spain) grant number IND2017/TIC7714.

Conflicts of Interest: The authors declare no conflict of interest.

\section{Abbreviations}

ANN Artificial neural network

AS-MLC Metal oxide semiconductor sensor for detection of carbon monoxide, manufactured by Applied Sensor Technologies

AS-MLK Metal oxide semiconductor sensor, manufactured by Applied Sensor Technologies

AS-MLN Metal oxide semiconductor sensor for detection of nitrogen monoxide sensor, manufactured by Applied Sensor Technologies

AS-MLV Metal oxide semiconductor sensor for detection and reduction of gases such as VOCs and CO,

AS-MLV manufactured by Applied Sensor Technologies

BAL Bronchoalveolar lavage

BP Backpropagation

CDA Canonical discriminant analysis

CO Carbon monoxide

CRBM Convolutional restricted Boltzmann machine (a type of probabilistic neural network)

CVA Cross-validated accuracy

CVV Cross-validation value

DFA Discriminant function analysis

FNN Feedforward neural network

GC Gas chromatography

$\mathrm{H}_{2} \mathrm{O}_{2} \quad$ Hydrogen peroxide

LAP Light-addressable potentiometric

LTB4 Leukotriene B4

MD Mahalanobis distance

MDA Malondialdehyde

MS Mass spectrometry

NMR Nuclear magnetic resonance

NO Nitric oxide

PCA Principal component analysis

PLS-DA Partial least squares-discriminant analysis

QCL Quantum cascade laser

ROC Receiver operating characteristic

SVM Support vector machine

\section{References}

1. Professional Practice Committee: Standards of Medical Care in Diabetes-2018. Diabetes Care 2018, 41, S3. [CrossRef] [PubMed]

2. Breath Biopsy: The Complete Guide. Volatile Ogranic Compounds (VOCs) as Biomarkers for Disesases. Available online: https://www.owlstonemedical.com/breath-biopsy-complete-guide/ (accessed on 20 September 2018).

3. World Health Organization (WHO). Life Expectancy Increased by 5 Years Since 2000, but Health Inequalities Persist. Available online: http:/ / www.who.int/news-room/19-05-2016-life-expectancy-increased-by-5years-since-2000-but-health-inequalities-persist (accessed on 21 October 2018).

4. World Health Organization Word report on ageing and health. Anim. Genet. 2015, 39, 561-563.

5. Wilkens, W.F.; Hartman, J.D. An Electronic Analog the Olfactory Processes. J. Food Sci. 1964, $29,372-378$. [CrossRef] 
6. Persaud, K.; Dodd, G. Analysis of discrimination mechanisms in the mammalian olfactory system using a model nose. Nature 1982, 299, 352-355. [CrossRef] [PubMed]

7. Gardner, J.W.; Bartlett, P.N. A brief history of electronic noses. Sens. Actuators 1994, 18-19, 210-211. [CrossRef]

8. Wilson, A.D. Diverse applications of electronic-nose technologies in agriculture and forestry. Sensors 2013, 13, 2295-2348. [CrossRef] [PubMed]

9. Ghasemi-Varnamkhasti, M.; Apetrei, C.; Lozano, J.; Anyogu, A. Potential use of electronic noses, electronic tongues and biosensors as multisensor systems for spoilage examination in foods. Trends Food Sci. Technol. 2018, 80, 71-92. [CrossRef]

10. Zhang, X.; Cheng, J.; Wu, L.; Mei, Y.; Jaffrezic-Renault, N.; Guo, Z. An overview of an artificial nose system. Talanta 2018, 184, 93-102. [CrossRef] [PubMed]

11. Santos, J.P.; Lozano, J.; Aleixandre, M. Brewing Technology Chapter 9: Electronic Noses Applications in Beer Technology; Kanauchi, M., Ed.; InTechOpen: Lodon, UK, 2017. [CrossRef]

12. Pearce, T.C.; Schiffman, S.S.; Nagle, H.T.; Gardner, J.W. Handbook of Machine Olfaction; John Wiley \& Sons: Hoboken, NJ, USA, 2014; ISBN 047186109X.

13. Lozano, M.; Horrillo, M.; Aleixandre, M.C.; Santos, J.P.; Fernández, M.; Sayago, I.; Gutiérrez, J.L.; Fontecha, J. Olfative Sensor Systems for the Wine-Producing Industry. Food 2007, 1, $23-29$.

14. Correa Hernando, E.C.; Barreiro Elorza, P.; Ruiz-Altisent, M.; Chamorro Valencia, M.C. Nariz electrónica ¿herramienta para la calidad en la industria agroalimentaria? «II Congreso Nacional de Calidad Alimentaria». Available online: http:/ / www.agro-alimentarias.coop/ficheros/doc/01297 (accessed on 25 October 2018).

15. Adlard, E.R.; Poole, C.F. Gas Chromatography: Historical Development; Elsevier Inc.: Amsterdam, The Netherlands, 2018; ISBN 9780124095472.

16. Kolomnikov, I.G.; Efremov, A.M.; Tikhomirova, T.I.; Sorokina, N.M.; Zolotov, Y.A. Early stages in the history of gas chromatography. J. Chromatogry A 2018, 1537, 109-117. [CrossRef] [PubMed]

17. Vas, G.; Vékey, K. Solid-phase microextraction: A powerful sample preparation tool prior to mass spectrometric analysis. J. Mass Spectrom. 2004, 39, 233-254. [CrossRef] [PubMed]

18. Amann, A.; Costello, B.D.L.; Miekisch, W.; Schubert, J.; Buszewski, B.; Pleil, J.; Ratcliffe, N.; Risby, T. The human volatilome: Volatile organic compounds (VOCs) in exhaled breath, skin emanations, urine, feces and saliva. J. Breath Res. 2014, 8. [CrossRef] [PubMed]

19. Kostikas, K.; Bakakos, P.; Loukides, S. General Methods in Biomarker Research and their Applications; Preedy, V.R., Patel, V.B., Eds.; Springer: Dordrecht, The Ntherlands, 2014; pp. 1-25. [CrossRef]

20. Céspedes Miranda, E.; Castillo Herrera, J. La peroxidación lipídica en el diagnostico del estrés oxidativo del paciente hipertenso. ¿Realidad o mito? Rev. Cubana Investig. Bioméd. 2008, 27. Available online: http:/ / scielo.sld.cu/scielo.php?script=sci_arttext\&pid=S0864-03002008000200003 (accessed on 25 October 2018).

21. Shorter, J.H.; Nelson, D.D.; McManus, J.B.; Zahniser, M.S.; Sama, S.R.; Milton, D.K. Clinical study of multiple breath biomarkers of asthma and COPD $\left(\mathrm{NO}, \mathrm{CO}_{2}, \mathrm{CO}\right.$ and $\left.\mathrm{N}_{2} \mathrm{O}\right)$ by infrared laser spectroscopy. J. Breath Res. 2011, 5, 037108. [CrossRef] [PubMed]

22. Phillips, M.; Cataneo, R.N.; Cummin, A.R.C.; Gagliardi, A.J.; Gleeson, K.; Greenberg, J.; Maxfield, R.A.; Rom, W.N. Detection of Lung Cancer With Volatile Markers in the Breath. Chest 2003, 123, 2115-2123. [CrossRef] [PubMed]

23. D'Amico, A.; Pennazza, G.; Santonico, M.; Martinelli, E.; Roscioni, C.; Galluccio, G.; Paolesse, R.; Di Natale, C. An investigation on electronic nose diagnosis of lung cancer. Lung Cancer 2010, 68, 170-176. [CrossRef] [PubMed]

24. Asthma: MedlinePlus Medical Encyclopedia. Available online: https://medlineplus.gov/ency/article/ 000141.htm (accessed on 20 October 2018).

25. COPD: MedlinePlus Medical Encyclopedia. Available online: https://medlineplus.gov/copd.html (accessed on 20 October 2018).

26. Lärstad, M.A.E.; Torén, K.; Bake, B.; Olin, A.C. Determination of ethane, pentane and isoprene in exhaled air-Effects of breath-holding, flow rate and purified air. Acta Physiol. 2007, 189, 87-98. [CrossRef] [PubMed]

27. Paredi, P.; Kharitonov, S.A.; Barnes, P.J. Elevation of Exhaled Ethane Concentration in Asthma. Am. J. Respir. Crit. Care Med. 2000, 162, 1450-1454. [CrossRef] [PubMed]

28. Acute Respiratory Distress Syndrome: MedlinePlus Medical Encyclopedia. Available online: https:// medlineplus.gov/ency/article/000103.htm (accessed on 24 October 2018). 
29. Cystic Fibrosis: MedlinePlus Medical Encyclopedia. Available online: https://medlineplus.gov/cysticfibrosis. html (accessed on 21 October 2018).

30. Antuni, J.D.; Kharitonov, S.A.; Hughes, D.; Hodson, M.E.; Barnes, P.J. Increase in exhaled carbon monoxide during exacerbations of cystic fibrosis. Thorax 2000, 55, 138-142. [CrossRef] [PubMed]

31. Lung Cancer: MedlinePlus Medical Encyclopedia. Available online: https://medlineplus.gov/lungcancer. html (accessed on 21 October 2018).

32. Bajtarevic, A.; Ager, C.; Pienz, M.; Klieber, M.; Schwarz, K.; Ligor, M.; Ligor, T.; Filipiak, W.; Denz, H.; Fiegl, M.; et al. Noninvasive detection of lung cancer by analysis of exhaled breath. BMC Cancer 2009, 9, 348. [CrossRef] [PubMed]

33. Olopade, C.O.; Zakkar, M.; Swedler, W.I.; Rubinstein, I. Exhaled pentane levels in acute asthma. Chest 1997, 111, 862-865. [CrossRef] [PubMed]

34. Dweik, R.A.; Boggs, P.B.; Erzurum, S.C.; Irvin, C.G.; Leigh, M.W.; Lundberg, J.O.; Olin, A.-C.; Plummer, A.L.; Taylor, D.R.; et al. An official ATS clinical practice guideline: interpretation of exhaled nitric oxide levels (FENO) for clinical applications. Am. J. Respir. Crit. Care Med. 2011, 184, 602-615. [CrossRef] [PubMed]

35. Paredi, P.; Kharitonov, S.A.; Leak, D.; Ward, S.; Cramer, D.; Barnes, P.J. Exhaled Ethane, a Marker of Lipid Peroxidation, Is Elevated in Chronic Obstructive Pulmonary Disease. Am. J. Respir. Crit. Care Med. 2000, 162, 369-373. [CrossRef] [PubMed]

36. Barker, M.; Hengst, M.; Schmid, J.; Buers, H.-J.; Mittermaier, B.; Klemp, D.; Koppmann, R. Volatile organic compounds in the exhaled breath of young patients with cystic fibrosis. Eur. Respir. J. 2006, 27, 929-936. [CrossRef] [PubMed]

37. Das, S.; Pal, S.; Mitra, M. Significance of Exhaled Breath Test in Clinical Diagnosis: A Special Focus on the Detection of Diabetes Mellitus. J. Med. Biol. Eng. 2016, 36, 605-624. [CrossRef] [PubMed]

38. Španěl, P.; Dryahina, K.; Rejšková, A.; Chippendale, T.W.E.; Smith, D. Breath acetone concentration; Biological variability and the influence of diet. Physiol. Meas. 2011, 32. [CrossRef] [PubMed]

39. Kearney, D.J.; Hubbard, T.; Putnam, D. Breath ammonia measurement in Helicobacter pylori infection. Dig. Dis. Sci. 2002, 47, 2523-2530. [CrossRef] [PubMed]

40. Metz, G.; Jenkins, D.J.; Peters, T.J.; Newman, A.; Blendis, L.M. Breath hydrogen as a diagnostic method for hypolactasia. Lancet 1975, 1, 1155-1157. [CrossRef]

41. Alkhouri, N.; Singh, T.; Alsabbagh, E.; Guirguis, J.; Chami, T.; Hanouneh, I.; Grove, D.; Lopez, R.; Dweik, R. Isoprene in the Exhaled Breath is a Novel Biomarker for Advanced Fibrosis in Patients with Chronic Liver Disease: A Pilot Study. Clin. Transl. Gastroenterol. 2015, 6, e112. [CrossRef] [PubMed]

42. Diabetes: MedlinePlus Medical Encyclopedia. Available online: https://medlineplus.gov/diabetes.html (accessed on 30 October 2018).

43. Bataller, R.; Brenner, D.A. Liver fibrosis. J. Clin. Investig. 2005, 115, 209-218. [CrossRef] [PubMed]

44. Lember, M. Hypolactasia: A common enzyme deficiency leading to lactose malabsorption and intolerance. Pol. Arch. Med. Wewn. 2012, 122 (Suppl. 1), 60-64.

45. Pneumonia: MedlinePlus Medical Encyclopedia. Available online: https://medlineplus.gov/pneumonia. html (accessed on 31 October 2018).

46. Nahid, P.; Dorman, S.E.; Alipanah, N.; Barry, P.M.; Brozek, J.L.; Cattamanchi, A.; Chaisson, L.H.; Chaisson, R.E.; Daley, C.L.; Grzemska, M.; et al. Official American Thoracic Society/Centers for Disease Control and Prevention/Infectious Diseases Society of America Clinical Practice Guidelines: Treatment of Drug-Susceptible Tuberculosis. Clin. Infect. Dis. 2016, 63, e147-e195. [CrossRef] [PubMed]

47. Mathew, T.L.; Pownraj, P.; Abdulla, S.; Pullithadathil, B. Technologies for Clinical Diagnosis Using Expired Human Breath Analysis. Diagnostics 2015, 5, 27-60. [CrossRef] [PubMed]

48. Gibson, L.E.; Cooke, R.E. A test for concentration of electrolytes in sweat in cystic fibrosis of the pancreas utilizing pilocarpine by iontophoresis. Pediatrics 1959, 23, 545-549. [PubMed]

49. Dragonieri, S.; Schot, R.; Mertens, B.J.A.; Le Cessie, S.; Gauw, S.A.; Spanevello, A.; Resta, O.; Willard, N.P.; Vink, T.J.; Rabe, K.F.; et al. An electronic nose in the discrimination of patients with asthma and controls. J. Allergy Clin. Immunol. 2007, 120, 856-862. [CrossRef] [PubMed]

50. Dragonieri, S.; Quaranta, V.N.; Carratu, P.; Ranieri, T.; Resta, O. Exhaled breath profiling by electronic nose enabled discrimination of allergic rhinitis and extrinsic asthma. Biomarkers 2018, 1-24. [CrossRef] [PubMed] 
51. Brinkman, P.; van de Pol, M.A.; Gerritsen, M.G.; Bos, L.D.; Dekker, T.; Smids, B.S.; Sinha, A.; Majoor, C.J.; Sneeboer, M.M.; Knobel, H.H.; et al. Exhaled breath profiles in the monitoring of loss of control and clinical recovery in asthma. Clin. Exp. Allergy 2017, 12, 3218-3221. [CrossRef] [PubMed]

52. Dymerski, T.; Gebicki, J.; Wiśniewska, P.; Śliwińska, M.; Wardencki, W.; Namieśnik, J. Application of the electronic nose technique to differentiation between model mixtures with COPD markers. Sensors 2013, 13, 5008-5027. [CrossRef] [PubMed]

53. Zetola, N.M.; Modongo, C.; Matsiri, O.; Tamuhla, T.; Mbongwe, B.; Matlhagela, K.; Sepako, E.; Catini, A.; Sirugo, G.; Martinelli, E.; et al. Diagnosis of pulmonary tuberculosis and assessment of treatment response through analyses of volatile compound patterns in exhaled breath samples. J. Infect. 2017, 74, 367-376. [CrossRef] [PubMed]

54. Bruins, M.; Rahim, Z.; Bos, A.; Van De Sande, W.W.J.; Endtz, H.P.; Van Belkum, A. Diagnosis of active tuberculosis by e-nose analysis of exhaled air. Tuberculosis 2013, 93, 232-238. [CrossRef] [PubMed]

55. Fend, R.; Kolk, A.H.J.; Bessant, C.; Buijtels, P.; Klatser, P.R.; Woodman, A.C. Prospects for clinical application of electronic-nose technology to early detection of Mycobacterium tuberculosis in culture and sputum. J. Clin. Microbiol. 2006, 44, 2039-2045. [CrossRef] [PubMed]

56. Saasa, V.; Malwela, T.; Beukes, M.; Mokgotho, M.; Liu, C.-P.; Mwakikunga, B. Sensing Technologies for Detection of Acetone in Human Breath for Diabetes Diagnosis and Monitoring. Diagnostics 2018, 8. [CrossRef] [PubMed]

57. Schnabel, R.M.; Boumans, M.L.L.; Smolinska, A.; Stobberingh, E.E.; Kaufmann, R.; Roekaerts, P.M.H.J.; Bergmans, D.C.J.J. Electronic nose analysis of exhaled breath to diagnose ventilator-associated pneumonia. Respir. Med. 2015, 109, 1454-1459. [CrossRef] [PubMed]

58. Montuschi, P.; Santonico, M.; Mondino, C.; Pennazza, G.; Maritini, G.; Martinelli, E.; Capuano, R.; Ciabattoni, G.; Paolesse, R.; Di Natale, C.; et al. Diagnostic performance of an electronic nose, fractional exhaled nitric oxide, and lung function testing in asthma. Chest 2010, 137, 790-796. [CrossRef] [PubMed]

59. Santonico, M.; Zompanti, A.; Vernile, C.; Pennazza, G.; Brinkman, P.; Wagener, A.H.; Sterk, P.J.; D’Amico, A.; Montuschi, P. An investigation on e-nose platform relevance to respiratory diseases. In Proceedings of the IEEE Sensors, Valencia, Spain, 2-5 November 2014; pp. 688-690. [CrossRef]

60. Cavaleiro Rufo, J.; Paciência, I.; Mendes, F.C.; Farraia, M.; Rodolfo, A.; Silva, D.; de Oliveira Fernandes, E.; Delgado, L.; Moreira, A. Exhaled breath condensate volatilome allows sensitive diagnosis of persistent asthma. Allergy 2018. [CrossRef] [PubMed]

61. Capuano, R.; Santonico, M.; Martinelli, E.; Pennazza, G.; Paolesse, R.; Bergamini, A.; Cazzola, M.; Ciaprini, C.; Di Natale, C.; D'Amico, A. COPD diagnosis by a gas sensor array. Procedia Eng. 2010, 5, 484-487. [CrossRef]

62. Hattesohl, A.D.M.; Jörres, R.A.; Dressel, H.; Schmid, S.; Vogelmeier, C.; Greulich, T.; Noeske, S.; Bals, R.; Koczulla, A.R. Discrimination between COPD patients with and without alpha 1-antitrypsin deficiency using an electronic nose. Respirology 2011, 16, 1258-1264. [CrossRef] [PubMed]

63. Bofan, M.; Mores, N.; Baron, M.; Dabrowska, M.; Valente, S.; Schmid, M.; Trové, A.; Conforto, S.; Zini, G.; Cattani, P.; et al. Within-day and between-day repeatability of measurements with an electronic nose in patients with COPD. J. Breath Res. 2013, 7, 017103. [CrossRef] [PubMed]

64. Bos, L.D.J.; Schultz, M.J.; Sterk, P.J. Exhaled breath profiling for diagnosing acute respiratory distress syndrome. BMC Pulm. Med. 2014, 14, 72. [CrossRef] [PubMed]

65. Dragonieri, S.; Brinkman, P.; Mouw, E.; Zwinderman, A.H.; Carratú, P.; Resta, O.; Sterk, P.J.; Jonkers, R.E. An electronic nose discriminates exhaled breath of patients with untreated pulmonary sarcoidosis from controls. Respir. Med. 2013, 107, 1073-1078. [CrossRef] [PubMed]

66. Paff, T.; van der Schee, M.P.; Daniels, J.M.A.; Pals, G.; Postmus, P.E.; Sterk, P.J.; Haarman, E.G. Exhaled molecular profiles in the assessment of cystic fibrosis and primary ciliary dyskinesia. J. Cyst. Fibros. 2013, 12, 454-460. [CrossRef] [PubMed]

67. Di Natale, C.; Macagnano, A.; Martinelli, E.; Paolesse, R.; D’Arcangelo, G.; Roscioni, C.; Finazzi-Agrò, A.; D'Amico, A. Lung cancer identification by the analysis of breath by means of an array of non-selective gas sensors. Biosens. Bioelectron. 2003, 18, 1209-1218. [CrossRef]

68. Machado, R.F.; Laskowski, D.; Deffenderfer, O.; Burch, T.; Zheng, S.; Mazzone, P.J.; Mekhail, T.; Jennings, C.; Stoller, J.K.; Pyle, J.; et al. Detection of Lung Cancer by Sensor Array Analyses of Exhaled Breath. Am. J. Respir. Crit. Care Med. 2005, 171, 1286-1291. [CrossRef] [PubMed] 
69. Dragonieri, S.; Annema, J.T.; Schot, R.; van der Schee, M.P.C.; Spanevello, A.; Carratú, P.; Resta, O.; Rabe, K.F.; Sterk, P.J. An electronic nose in the discrimination of patients with non-small cell lung cancer and COPD. Lung Cancer 2009, 64, 166-170. [CrossRef] [PubMed]

70. Dragonieri, S.; Van Der Schee, M.P.; Massaro, T.; Schiavulli, N.; Brinkman, P.; Pinca, A.; Carratú, P.; Spanevello, A.; Resta, O.; Musti, M.; et al. An electronic nose distinguishes exhaled breath of patients with Malignant Pleural Mesothelioma from controls. Lung Cancer 2012, 75, 326-331. [CrossRef] [PubMed]

71. American Cancer Society Estadísticas importantes sobre el cáncer de pulmón. Available online: https: / / www.cancer.org/es/cancer/cancer-de-pulmon-no-microcitico/acerca/estadisticas-clave.html (accessed on 4 September 2018).

72. Hockstein, N.G.; Thaler, E.R.; Lin, Y.; Lee, D.D.; Hanson, C.W. Correlation of pneumonia score with electronic nose signature: A prospective study. Ann. Otol. Rhinol. Laryngol. 2005, 114, 504-508. [CrossRef] [PubMed]

73. Chiu, S.; Member, S.; Wang, J.; Chang, K.; Chang, T.; Wang, C.; Chang, C.; Tang, C.; Chen, C.; Shih, C.; et al. A Fully Integrated Nose-on-a-Chip for Rapid Diagnosis of Ventilator- Associated Pneumonia. IEEE Trans. Biomed. Circuits Syst. 2015, 8, 2015. [CrossRef]

74. Pavlou, A.K.; Magan, N.; Jones, J.M.; Brown, J.; Klatser, P.; Turner, A.P.F. Detection of Mycobacterium tuberculosis $(\mathrm{TB})$ in vitro and in situ using an electronic nose in combination with a neural network system. Biosens. Bioelectron. 2004, 20, 538-544. [CrossRef] [PubMed]

75. Coronel Teixeira, R.; Rodríguez, M.; Jiménez de Romero, N.; Bruins, M.; Gómez, R.; Yntema, J.B.; Chaparro Abente, G.; Gerritsen, J.W.; Wiegerinck, W.; Pérez Bejerano, D.; et al. The potential of a portable, point-of-care electronic nose to diagnose tuberculosis. J. Infect. 2017, 75, 441-447. [CrossRef] [PubMed]

76. Mohamed, E.I.; Mohamed, M.A.; Moustafa, M.H.; Abdel-Mageed, S.M.; Moro, A.M.; Baess, A.I.; El-Kholy, S.M. Qualitative analysis of biological tuberculosis samples by an electronic nose-based artificial neural network. Int. J. Tuberc. Lung Dis. 2017, 21, 810-817. [CrossRef] [PubMed]

(C) 2019 by the authors. Licensee MDPI, Basel, Switzerland. This article is an open access article distributed under the terms and conditions of the Creative Commons Attribution (CC BY) license (http:/ / creativecommons.org/licenses/by/4.0/). 